This is an Accepted Manuscript of an article published by Intellect in International Journal of Digital Television on 2016, available online: https://www.ingentaconnect.com/content/intellect/jdtv/2016/00000007/000 00002/art00006 


\title{
Gender, generation and reception of Spanish television fiction in the digital age
}

\section{CHARO LACALLE AND CRISTINA PUJOL}

Autonomous University of Barcelona

\begin{abstract}
Media convergence has considerably modified television-viewing practices. The interaction of the television with second screens has generated new ways of communicating between viewers, which they do while simultaneously watching television. This study combines focus groups and questionnaires to examine, from a generational perspective, the relationship between female viewers and Spanish television fiction and the resulting interactions conducted both face-to-face and through new technologies. The results question the view that female members of the digital generation interviewed watch media products in isolation and demonstrate that the social aspect of television viewing is one of its greatest pleasures. In general terms, our contribution confirms the influence of the generation gap on viewers' preferences and their different ways of watching television. Therefore, the solidarity established between women to maintain and prolong viewing pleasure helps to mitigate the digital gap between older and younger female participants.
\end{abstract}

\section{KEYWORDS}

reception

TV fiction

Internet

gender

generation 
digital technologies

\section{INTRODUCTION}

The Internet, media convergence and new media forms have changed the way in which television is viewed, with audiences watching while simultaneously carrying out other daily activities such as 'reading, shopping, voting, playing, researching, writing, chatting' (Livingstone 2004: 2). This represents an important challenge for studies on reception, which focused in the past on the relationship between the audience and media texts, the deconstruction of meanings and the role of new technologies in home information (Ang 1985; Fiske 1986; Hall 1997; Gillespie 1995; Morley 1980; Walkerdine 1986). Researchers defend the notion of a sophisticated, aware, active audience made up of viewers and consumers who are critical of the media (Buckingham and Bragg 2004; Jackson and Vares 2011) and who are 'involved in produsage -the collaborative and continuous building and extending of existing content in pursuit of further improvement' (Bruns 2007, emphasis added).

This article forms part of a broader project on the construction of female identity in television and new technologies. This study combines focus groups and questionnaires with the aim of exploring, from the perspective of generations, the relationship between female viewers and Spanish television fiction and their interactions, both face-to-face and through new technologies.

\section{GENDER AND TELEVISION: EMOTIONS ARE AT THE CENTRE}

Gender identity is a determining factor in the consumption of television fiction. Early studies on the subject focused on housewives, a social collective highly sought after by television networks and advertisers but generally ignored by media 
communication studies until the end of the 1970s. It is, therefore important to point out that the legitimization of television studies - the process of analysing and giving rigorous thought to television products and consumption - occurred in parallel with the legitimization of its audience, especially women (Brunsdon 2000; Hollows 2000). From a gender perspective, viewers' opinions of television fiction not only provides information about their cultural tastes but also about their interactions, their transmedia relationship with programmes, the integration of new technologies into their lives and the communication networks and unity existing between women of different generations and social classes.

The ethnographic studies carried out at the end of the 1970s began to listen to female viewers, generally housewives, without pre-established prejudices or axioms. Thus, Modlesky (1982) states that soap opera viewers look for a 'fantasy community' that helps them alleviate their worries and the loneliness of being at home. Hobson (1982) concludes that women's enjoyment of such programmes went beyond simple entertainment or distraction: watching television allowed them to relax, rest and eliminate the stresses of daily life while familiarity with the characters helped mitigate feelings of isolation and relieve the boredom of doing household chores. Ang (1985) observed that female viewers activated a process termed 'emotional realism' in their interpretations of what they saw on television through a comparison of their personal experiences with those of the television characters, which allowed them to identify with their actions and values independently of their contextual and cultural differences. Geraghty (1991) observed that women valued the conversation and dialogue of the characters over actions, demonstrating their emotional and personal relationship with the programmes. 
The characteristics of the new media ecosystem favour a cross-media, mobile, flexible, shared consumption and reveal the generational differences in viewing preferences and the uses of technology (boyd 2008; Livingstone 2008, 2009). Consequently, the paradigm of a participative culture prevails: a communication model that allows the audience to interact with television content (Jenkins 2006). Today's programmes are perfectly adapted to the Internet 2.0 such that networks and producers favour, in terms of the creative process itself, the uses of media content with social networks and new technologies (Scolari 2010).

Pioneering studies on online ethnography (Turkle 1997; Baym 1998) revealed the existence of virtual communities in which the participants shared identities, resources, ideas and practices and lent each other constant technological support. Madill and Goldmeier (2003) demonstrated that the use of the Internet by fans of the series Eastenders (1985-) to comment on the plots increased viewing experience. More recent investigations on communication practices in social networks similarly reveal the role played by intergenerational communication and the strengthening of family ties (Gonçalves and Patrício 2010; Siibak and Tamme 2013). It is also worth pointing out the role of the relationship between modern technologies and generational identities in users' sense of belonging and generational cohesion (Aroldi 2011; Napoli 2014).

In general, audiences opt for viewing practices and Internet uses that are the 'most friendly for them' (Simons 2013: 189) and prefer contents that 'they find relevant, appealing, and easily understood' (Tehone et al. 2015: 352). Women use the Internet more than men to communicate and interact with each other, although in North America this gap had decreased by $2014 .{ }^{1}$ They tend to share their experiences more socially (Doyle 2009) and create a greater amount of online content (Lenhart et 
al. 2007). Nevertheless, the sexism that exists in the real world also exists in its virtual counterpart, since women expressing unpopular points of view are usually criticized for being women, while men are attacked for defending these ideas (Baym 2010: 67). Kehily and Nayak (2008) point out the role of the relationship between young women and television and ICTs (Information and Communication Technologies) in the construction of new gender roles and definitions.

\section{Television fiction, gender and generation}

The increasing use of mobile technologies in audio-visual consumption is an important feature of the social changes experienced by western societies in recent decades. Multi-platform viewing, content tagging, downloading, streaming and bingewatching represent different forms of a 'social television' that no longer requires physical proximity to watch contents in company. In addition to popular social networks such as Twitter and Facebook, other television 2.0 applications, including Tuitele, Tockit and Shazam, allow live commenting on programmes, interaction on Twitter, access to television guides and the creation of programme-dedicated groups, not to mention the numerous forums hosted both on the networks' official pages and sites created by the fans themselves (Deery 2003; Siapera 2004; Williams 2015).

Television fiction consumption is increasingly individualized and nomadic, ${ }^{2}$ and mobile phones are personalized screens through which viewers create their own viewing schedules (Barkhuus 2009; Álvarez Monzoncillo 2011). However, these technological, sociocultural global changes are conditioned by two important sociological variables. First, Spanish women watch 27 minutes more television per day than Spanish men ${ }^{3}$ and second, most Spanish households are multigenerational. In fact, two-thirds of Spanish households consist of two or more generations (children, 
parents and even grandparents), a tradition characteristic of the Mediterranean area that has been accentuated in recent years by the economic crisis (Moreno Minguez 2012). Thus, one in two young Spanish people between the ages of 25 and 29 (48.5 per cent) and one in five adults aged 30 to 34 (20.5 per cent) still live with their parents (INE 2014 ${ }^{4}$. This 'forced cohabitation' accentuates the fact that the break-up of the traditional central location of the television set within the living room also implies a change in family hierarchy in terms of television viewing and demonstrates existing generation gaps (Álvarez Monzoncillo 2011). Thus, increasing numbers of young people are used to free copying, the lack of a central node in the media structure, almost unlimited content availability, multitasking and social television. The possibility of watching television simultaneously with their peers through a mobile phone from the same sofa they share with their parents - who monopolize the television remote control - allows them to see power relationships in a very different way, thereby increasing their feeling of empowerment they get from 'a la carte' viewing (Barkhuus 2009).

Gender and generation are, therefore, two important parameters that need to be taken into account when considering the different relationships between viewers and television fiction. While gender determines preferences and viewing modes of both women and men (Lacalle 2012), generation is a crucial factor in viewing practices (Livingstone et al. 2001). A good example of this would be 'binge-watching':

Two-thirds of viewers 'binge-watch' TV, watching three or more episodes of TV in one sitting. Millennials overwhelmingly engage in binge-watching behaviors [...]. There are some gender differences among binge-watchers, with women being more likely to binge on dramas and men being more likely than women to 
binge on comedies. (Deloitte 2015: 11)

Siibak et al. claim that individuals' identity construction and their sense of belonging to a generation are intimately tied to technologies and the media. Following Aroldi (2011) and Aroldi and Colombo (2013), the authors consider that this process takes place on two levels: on the one hand, media experiences during an individual's period of education determine the definition of generations and cultures of media consumption and on the other, media representations, choices and technologies contribute to identity construction and the sense of belonging to a generation (Siibak et al. 2014: 101).

A number of European studies, carried out through focus groups, demonstrate the importance of generation-oriented questions in relation to leisure time and the use of technologies. Bolin (2014) analysed the differences between the 'objective' media panorama and viewers' 'subjective' perceptions and experiences and observed a twofold feeling of nostalgia. On the one hand, this nostalgia is related to infancy and refers to the memories and experiences of each of the participants during this important phase of their lives. Second, nostalgia is associated with an individual's period in education and is more closely associated with a feeling of belonging to a particular generation. The study carried out by Landabidea (2014) relates viewing with leisure time experiences among peer groups and the way these individuals perceive and experience television. Napoli demonstrates that younger generations identify the Internet as a microcosm, the result of the work of and interactions with their peers, while baby boomers and the generation $\mathrm{X}$ see social networks as a space populated by individuals of different ages and generations (2014: 202). This same author's analysis of television viewing similarly reveals that collective memory is not 
shared on the Internet but, rather, the opposite: 'each generation is limited to a transferral process of the same tensions onto the social web and the same mechanisms of inclusion and exclusion that are implemented offline' (Napoli 2014: 203).

\section{METHODS}

Focus groups were chosen to analyse television viewing since they are ideal for gathering objective data aimed at better understanding the real involvement and effects of television fiction consumption in the construction of cultural identities - in this case, generation and gender identities. Focus groups also facilitate the analysis of data in a more dynamic and flexible manner than other methods such as surveys, 'drawing on their [participants] pre-existing knowledge, attitudes and beliefs' (Holliman 2005: 11). Questionnaires, which are anonymous and individual, help us to identify the general television viewing practices and to determine the possible effects of the spiral of silence $e^{5}$ observed sometimes in group interviews. They also allow us to make more precise extrapolations on the range of the practices observed, with the necessary precaution that should be taken in any qualitative research (Alasuutari 1995).

The perceived limits of this study are associated with certain ethical considerations that should be taken into account in the use and treatment of both group interviews and individual, anonymous questionnaires. As Holliman states, audience research deals with the collecting private data, not public, and with the experiences related to meaning and not open practices (2005: 11), data that ultimately form part of the intimate experiences, feelings and emotional connections of people with the imaginaries and representations offered by television fictions. Therefore, the data extracted from an SPSS-coded questionnaire and which was aimed at 
complementing the analysis of group interviews has allowed us to make a more precise identification of the various practices observed in the investigation.

The study was carried out between November 2013 and February 2014, in twelve autonomous regions in Spain (Asturias, Andalusia, Aragon, the Canary Islands, Castile and León, Catalonia, the Community of Valencia, Extremadura, Galicia, the Balearic Islands, Madrid and the Basque Country). With the aim of facilitating interactions, we chose samples consisting of groups of women who knew each other beforehand and who met up regularly: friends, study mates or members of women's associations ('Housewives Association', 'My Women Association' and 'New Times Women's Association'). Moreover, in order to avoid the break-up of the organic structure of pre-existing groups, their spontaneous configuration was maintained, with between eight and twelve women making up each group. The sample consisted of a total of 124 women, divided into fourteen focus groups covering the following ages ranges: $10-14(\mathrm{~N}=18), 15-17(\mathrm{~N}=12), 18-21(\mathrm{~N}=21), 22-29(\mathrm{~N}=20), 30-45(\mathrm{~N}=16)$, 46-65 $(\mathrm{N}=18)$ and over-65 $(\mathrm{N}=19)$. All of the participants in the 10-14 and 15-17 age groups were school pupils. Total of $65 \%(\mathrm{~N}=13)$ of the young people in the $22-29$ age range were finishing their studies, while $30 \%(\mathrm{~N}=6)$ of the same group were working and only one $(0.5 \%)$ was unemployed. In total, $62.5 \%(\mathrm{~N}=10)$ of the women aged between 30 and 45 worked, while $37.5 \%(\mathrm{~N}=6)$ of the women from this group were unemployed. The women $(22.2 \%[\mathrm{~N}=4])$ in the $46-65$ age group worked, while $50.0 \%(\mathrm{~N}=9)$ were unemployed and $22.2 \%(\mathrm{~N}=4)$ were retired. Finally, $89.5 \%(\mathrm{~N}=17)$ of the over- 65 s were retired.

The interactions between the various pre-existing groups were guided by a female moderator, who used a semi-structured guide of the questions of a questionnaire compiled at the start of the session. This guide, that aimed to maintain 
the women's usual television fiction discussion groups, notably facilitated the subsequent data treatment. The group interviews were recorded into audio files and transcribed, respecting anonymity and the language used by each participant. The resulting interactions of the various issues addressed in the group interview were then classified using a template organized into themes. After coding the questionnaires using the statistical analysis programme SPSS, the data obtained allowed us to contextualize the qualitative analysis and to validate the participants' opinions, thereby detecting any possible contradictions between the individual replies to the questionnaire and the opinions expressed in the group discussion. The SPSS database includes 124 coded cases, which were used in a structured analysis using 54 variables closely linked to the proposed themes in the group interview, which were based on the following areas:

- Viewing: Reasons and frequency; most successful advertising strategies (trailers, the press, the Internet, personal recommendation etc.); viewing modes (in isolation/social, through the television set/on the Internet, interrupted/uninterrupted, unfocused attention/multitasking); consumption/production of related products and the extension of the television fiction to the Internet (creation of Internet resources, participation in forums or social networks, etc.).

- Preferences: Programmes, actors/actresses and favourite characters (gender, the role they play etc.); processes of identification/projection, etc.

- Interpretation: Themes; credibility/realism; extrapolation of the fiction onto daily life; viewers' narrative skills.

\section{RESULTS}


With up to three sets in some of the households of the women interviewed for this study, the television is still the main device for watching television fiction (91.1 per cent, $\mathrm{N}=113$ ), with watching on the Internet lying a considerable distance behind ( 8.9 per cent, $\mathrm{N}=11$ ). Female viewers from the latter group were distributed throughout the age ranges with the exception of 15 to 17 year olds and over- $65 \mathrm{~s}$, none of whom watched Spanish fiction programmes through the Internet.

Age is a determining factor in the social aspect of the participants' television viewing. Thus, the $10-14$-year-old $(61.1 \%, \mathrm{~N}=11)$ and the $15-17$-year-old $(75.0 \%$, $\mathrm{N}=9$ ) girls interviewed usually watched television with the rest of the family, while individual watching was concentrated in the $22-29(45.0 \%, \mathrm{~N}=9), 46-65(44.4 \%$, $\mathrm{N}=8)$ and over-65 age ranges $(84.2 \%, \mathrm{~N}=16)$, some of whom chose to watch on their own so as to give the programme their full attention. A total of $74.2 \%(\mathrm{~N}=92)$ of the female participants assured that they chose the programmes they watched. Watching with the rest of the family created tension, when mothers and daughters' preferences differed. Often, the remote control was the object of negotiation between adults and the 10-17-year-old girls interviewed in the study, who pointed out how much they had to insist in order to impose their preference.

The reality of multi-screen households is made evident when intergenerational preferences clash. In general, control of the main television, in agreement with their partner and children, by women aged 30 years and over has the following profile: 30 $45(43.8 \%, \mathrm{~N}=7), 46-65(61.1 \%, \mathrm{~N}=11)$ and over-65s $(84.2 \%, \mathrm{~N}=16)$, although the husband tends to control the main television during football matches. Some of the interviewed women pointed out that each household member has their own main television: 
E. (Vilagarcía de Arousa, 18-21 age range): In fact, in my house, everyone as their own main television. My mum's main TV is no longer the same as my dad's...

Generally, disagreements are resolved by using other devices or by strengthening habits that have developed over a period of time:

LS. (Alicante, 22-29 age range): Well, if my mum is watching something that I don't like, then I go to another telly.

Online viewing is the usual way to catch up on missed episodes, especially among the young girls and women aged $10-29$ years old $(54.71 \%, \mathrm{~N}=29)$, a habit that decreases progressively in women over $30(22.64 \%, \mathrm{~N}=12) .{ }^{6}$ Multitasking is common practise while watching on the computer and is quite popular among girls aged 10-14 years old $(44.4 \%, \mathrm{~N}=8)$ and young women aged $22-29(45.0 \%, \mathrm{~N}=9)$, while girls in the intervening age ranges (15-17 and 18-21) associate watching television with the use of mobiles and utilize second screens to recommend the programme they are watching.

Commercials are used mainly by young women aged 22-29 years old (45.0 per cent, $N=9$ ) to carry out other activities such as chatting or making telephone calls and even use their mobile phones to warn their female friends that the adverts have finished:

So. (Vilagarcía de Arousa, 22-29 age range): Hey, the ads are over! 
Women over 65 years of age, on the other hand, do not usually skip adverts $(84.2 \%, \mathrm{~N}=16)$ and even claim that they act as a distraction. These data are consistent with the solitary nature of the viewing practices of female participants from this age group $(73.7 \%, \mathrm{~N}=14)$, most of whom $(82.4 \%, \mathrm{~N}=16)$ do not watch the programmes in the company of others generally because they live on their own. Hence, for nearly all of them, television programmes help them schedule their day while at the same time keeping them company.

Despite the boom in technologies and the democratization of mobile phones, $94.4 \%(\mathrm{~N}=117)$ of the women interviewed discuss fiction programmes mainly during their face-to-face interactions. In total, $10.5 \%(\mathrm{~N}=13)$ of those interviewed use these interactions to catch up on missed episodes, with their female friends filling them in on the details of the programme's events. Nevertheless, $30.6 \%(\mathrm{~N}=38)$, mainly young girls in the $10-14(66.7 \%, \mathrm{~N}=12)$ and $15-17(75.0 \%, \mathrm{~N}=9)$ age ranges, use the Internet to look for additional information about the programmes, although participation in forums and social networks is low $(11.3 \%, \mathrm{~N}=14)$ and only one female participant had created resources related to the programmes that she followed. Occasionally, some of the young girls interviewed helped older female members of their family to bridge the digital gap, keeping them up to date with the latest news on a particular series, which they obtained through social networks or official web pages:

G. (Palma, 15-17 age range): My parents don't have Facebook but have been following the series since the first episode. They love it and have asked me to thank the Migjorn team for them. (Migjorn, IB3)

B. (Barcelona, 65+ age range): Well, I don't know anything about the Internet, 
but my granddaughter, who watches the series with me, told me that the other day she logged on to one of those things on the computer and said that she also watched it and that she watched it with her gran, in other words, me [...]

The help offered by young girls to older women in accessing technologies is reciprocated by the updates the latter give the former, who have difficulties following their favourite programmes due to family commitments:

M. B. (Valencia, 46-65 age range): I fill my daughter-in-law in with what's been going on [in the series] because when I go to see the grandchildren in the afternoon, she, since she's such an early bird, tells me 'I fell asleep'. So I tell her what happened.

The preference for soap operas creates a feeling of unity between women of different ages:

A. (Jerez de la Frontera, 30-45 age range): I watch [the series] with my daughter. The men go off and the women get together $[\ldots]$ In my case, it's me and my daughter. She loves the series just as much as I do.

\section{Preferences and interpretation}

Comedies and period dramas are the most popular programmes among the female participants, the most popular being La que se avecina (2007-), Aida (20052014) and Isabel (2012-2014). The first two are sitcoms, starring a community of middle-/middle-lower-class neighbours and a lower-class multigenerational family 
living on the outskirts of a big city, respectively, while Isabel is a period drama about the reign of Isabel I of Castile 'The Catholic' (1451-1504). Although there appeared to be no particular a priori theme of interest among the majority of women interviewed, romances tended to be the favourite among those aged 65 and over $(42.1 \%, \mathrm{~N}=8)$ and those in the $15-17$ age range $(58.3 \%, \mathrm{~N}=7)$. The latter also admitted that young, good-looking male stars were a decisive factor in their choice of Spanish series $(50 \%, \mathrm{~N}=6)$, something that also occurs in the $10-14$ age group $(66.6 \%$, $\mathrm{N}=12$ ).

In total, $66.7 \%$ of women aged $46-65(\mathrm{~N}=12)$ and $84.2 \%(\mathrm{~N}=16)$ of over- $65 \mathrm{~s}$ believe that, in general, the plots are realistic, which is in contrast to the opinion of girls aged $10-14(61.1 \%, \mathrm{~N}=11)$ and $22-29(55 \%, \mathrm{~N}=11)$. However, identification with the characters and the desire to imitate and look like them is mainly observed among girls aged $10-14$ years old $(50 \%, N=9)$ and $18-21(19 \%, N=4)$.

Finally, $74.1 \%(\mathrm{~N}=92)$ of the female participants perceive television fiction as an appealing leisure occupation, especially the youngest girls $(94.4 \%, \mathrm{~N}=17$ of the 10-14 year olds; $91.7 \%, \mathrm{~N}=11$ of the $15-17$ year olds) and older women $(89.5 \%$, $\mathrm{N}=17$ of over- $65 \mathrm{~s}$ ), a finding that is in line with the fact that female participants who watch Spanish fiction primarily to avoid their daily problems and obligations are aged between 24 and 65 . In other words, they belong to those age groups that most frequently have problems resulting from juggling work with family life: $45.0 \%(\mathrm{~N}=9)$ women aged $24-29 ; 31.3 \%(\mathrm{~N}=30)$ aged $30-45$ and $33.3 \%(\mathrm{~N}=6)$ aged $46-64$.

\section{DISCUSSION}

The results obtained call into question the notion of individual, independent television watching behaviours of members of the 'digital generation' as proposed by 
another Spanish study (Fedele and García Muñoz 2010). This is partly due to the fact that, as young women tend to live with their families, they watch certain programmes that they may not have chosen by themselves (Morales 2015). However, these results can also be partly explained by the fact that female participants try not to complicate their lives too much in order to watch the programmes that interest them (Simons 2013). The preference for comedies and for the 'freaky' or good-looking characters is consistent with the general conviction that television series are an attractive leisure activity and that female viewers have no particular expectations of them (Cooper 2003; Grandío 2007). This in agreement with the escapism role attributed to them by female participants (Lacalle 2012), which is an important aspect in the emotional connection of viewers of both genders with programmes (Gatfield and Millwood Hargrave 2003).

Despite the fact that solitary viewing gives audiences greater autonomy than watching with other household members, the social aspect of television consumption is one of the pleasures associated with watching television fiction. It can be concluded, therefore, that female participants see television as a social technology and, as such, although much of their viewing is done in isolation, their desire to share comments and emotional experiences with female friends and members of the family in the following days is undoubtedly related to the pleasure of watching (Kackman et al. 2011; Simons 2013). Moreover, television fiction provides them with 'topics to talk about and examples from which we can reflect on our lives and values' (Alasuutari 1992). The tendency to talk about the programmes face-to-face distances them from, at least for the moment, the spectre of 'dehumanizing isolation' brought about by the increasing role of modern technology in interpersonal relationships (Turkle 2015) and confirms the social nature of television fiction (Van den Bulck 2013). Our study also 
indicates that the communication established between women through television series (by discussing them, asking about episodes they have missed, etc.) nurtures emotional ties between female friends and intergenerational family relationships (Gonçalves and Patrício 2010; Siibak and Tamme 2013).

The digital gap is patent among the generations of Spanish people who share living spaces with multiple devices (Álvarez Monzoncillo 2011) and manifests itself in the way in which conflicts resulting from differences in viewing preferences are resolved. The relationship between the use of digital technologies and generational cohesion (Aroldi 2011; Napoli 2014) is evident in the case of the young girls and women who took part in our study, who interact with each other through the Internet more than the rest of the participants. Many of them multitask while watching their favourite programmes, 'typically surfing the web, e-mailing, texting, or social networking' (Deloitte 2015: 13). Programme recommendation is another common use for second screens while watching (Van Cauwenberge et al. 2014; Han and Lee 2014).

The practically non-existent creation of resources and information that complement the programme by the women interviewed confirms the scarce participation of most young people in uploading content onto the Internet (Coutois et al. 2009; Simons 2014). Consequently, although an intergenerational digital gap was also evident in this example (Dewan et al. 2005), there were no clear indications of the 'digital differentiation' claimed by other European studies carried out in the 2000s (Peter and Valkenburg 2006).

Finally, the analysis carried out here indicates that there is a more obvious relationship between the use of technologies and the social relationships established on the one hand by the baby boomers and generation $\mathrm{X}$ and, on the other, generation Y and generation Z (Napoli 2014). Our study also confirms the results of studies 
carried out by Landabidea (2014), and Landabidea and Loos (2015), which relate fiction consumption with leisure experiences among groups of the same age and the way in which these individuals see and experience television.

This study is in agreement with research that demonstrated the role of television fiction in the strengthening and transformation of the values of a particular community or social group. In general terms, our contribution confirms the influence of the generation gap on viewers' preferences and their different ways of watching television, although the similarity of female viewers' emotional relationship with television fiction calls into question the extent generally attributed to the generation gap in the area under investigation. Therefore, the solidarity established between women to maintain and prolong viewing pleasure helps to mitigate the digital gap between older and younger female participants.

\section{LIMITATIONS AND FUTURE DEVELOPMENTS}

This study has certain inherent limitations in terms of the qualitative methods due to the difficulties in extrapolating the results obtained from small sample sizes, in addition to other contextual factors. For example, the limited number of women interviewed who watch Spanish television only through mobile devices could have been due both to the sample size and the prime time schedule of most television series, which is the most popular time for family viewing. However, the small number of studies that address television viewing from the perspective of generation hinders the comparison of most of the results obtained here and highlights the need to study the long-term impact of television series on culture and socializing (Van den Bulck 2013).

The need to explore 'the complexity of interrelated online and offline practices in specific global circumstances' (Bird 2011: 512) is, likewise, another emerging area 
of investigation into television fiction consumption in the digital age, which has only been considered tangentially in this study, as has the specific analysis of the 'relationships of mutuality between technologies (texts) and users (readers)' (Das 2011: 344). Consequently, long-term research is required that allows us to understand and qualify the practices observed by numerous researchers who approach this subject from a generational and business perspective, such as the report by the prestigious multinational consultancy firm Deloitte, referred to previously.

\section{ACKNOWLEDGEMENTS}

This article is part of a larger investigation project entitled 'Social Construction of Women in the Television Fiction and Web 2.0: Stereotypes, Reception and Feedback' (FEM2012-33411), funded by the Spanish Ministry of Economy and Competitivity

(Government of Spain). This part of the research was developed by the authors and Deborah Castro, Beatriz Gómez (researchers); Meritxell Esquirol, Belén Granda, Rosa Ferrer, Raúl Rodríguez, Carlos Sanandrés, Karina Tiznado, Victoria Tur (contributors).

\section{REFERENCES}

Aída (2005-2014, Spain: Tele5).

Alasuutari, P. (1992), "I'm ashamed to admit it but I have watched Dallas": The moral hierarchy of television programmes', Media Culture Society, 14:4, pp. 561-82, http://mcs.sagepub.com. Accessed 1 December 2015. 
(1995), Researching Culture: Qualitative Method and Cultural Studies, London:

Sage.

Álvarez Monzoncillo, José María (2011), La televisión etiquetada. Nuevas audiencias, Nuevos negocios/`The labelled television. New audiences, new business’, Madrid: Ariel y Fundación Telefónica.

Ang, I. (1985), Watching Dallas. Soap Opera and the Melodramatic Imagination, Londres: Menthuen.

Aroldi, P. (2011), 'Generational belonging between media audiences and ICT users', in F. Colombo and L. Fortunati (eds), Broadband Society and Generational Changes, Frankfurt am Main: Peter Lang, pp. 51-68.

Aroldi, P. \& Colombo, F. (2013), 'Questioning Digital Global Generations. A Critical'. Approach. Northern Lights, 11, 175-190.

Barkhuus, L. (2009), 'Television on the Internet: New practices, new viewers', CHI, 4:9, pp. 2479-88.

Baym, N. K. (1998), The emergence of on-line community, in S. G. Jones (ed.), Cybersociety 2.0: Revisiting Computer-Mediated Communication and Community, Thousand Oaks, CA: Sage Publications, pp. 35-68. (2010), Personal Connections in the Digital Age, Malden, MA: Polity Press. 
Bird, E. (2011), 'Are we all produsers now?', Cultural Studies, 25:4-5, pp. 502-16, http://dx.doi.org/10.1080/09502386.2011.600532. Accessed 13 December 2015.

Bolin, G. (2014), 'Media generations: Objective and subjective media landscapes and nostalgia among generations of media users', Participations. Journal of Audience \& Reception Studies, 11:2, pp. 108-31.

boyd, d. m. (2008), 'Taken out of context: American teen sociality in networked publics', Ph.D. dissertation, Berkeley: University of California, School of Information, http://www.danah.org/papers/TakenOutOfContext.pdfBruns. Accessed 10 December 2015.

Bruns, A. (2007), 'Produsage: Towards a broader framework for user-led content creation, Proceedings Creativity \& Cognition, 6, http://eprints.qut.edu.au/6623/1/6623.pdf. Accessed 13 December 2015.

Brunsdon, C. (2000), The Feminist, the Housewife and the Soap Opera, Oxford: Clarendon Press.

Buckingham, D. and Bragg, S. (2004), Young People, Sex and the Media. Facts of Life?, Hampshire: Palgrave Macmillan.

Cooper, E. (2003), 'Decoding Will and Grace: Mass audience reception of a popular network situation comedy', Sociological Perspectives, 46:4, pp. 513-33. 
Coutois, C., Mechant, P., De Marez, L. and Verleye, G. (2009), 'Gratifications and seeding behavior of online adolescents', Journal of Computer-Mediated Communication, 15:1, pp. 109-37.

Das, R. (2011), 'Converging perspectives in audience studies and digital literacies: Youthful interpretations of an online genre', European Journal of Communication, 26:4, pp. $343-60$.

Deery, J. (2003), 'TV.com: Participatory viewing on the web', The Journal of Popular Culture, 37:2, pp. 161-83.

Deloitte (2015), 'Digital democracy survey. A multi-generational view of consumer technology, media and telecom trends', Deloitte Development LLC, http://www2.deloitte.com/content/dam/Deloitte/us/Documents/technology-mediatelecommunications/us-tmt-DDS_Executive_Summary_Report_Final_2015-0420.pdf. Accessed 13 December 2015.

Dewan, S., Ganley, S. and Kraemer, K. (2005), 'Across the digital divide: A crosscountry multi-technology analysis of the determinants of IT penetration', Journal of the Association for Information Systems, 6:12, pp. 409-32.

Doyle, S. (2009), 'Girls just wanna have fangs. The unwarranted backlash against fans of the world's most popular vampire-romance series', The American Prospect, 20:9, http://prospect.org/article/girls-just-wanna-have-fangs-0. Accessed 20 February 
2015.

Eastenders (1985-, UK: BBC1).

Fedele, M. and García Muñoz, N. (2010), 'El consumo adolescente de la ficción seriada'/'The adolescent consumption of serialized fiction', Vivat Academia, 111, http://pendientedemigracion.ucm.es/info/vivataca/numeros/n111/PDFs/Maddcop.pdf. Accessed 13 December 2015.

Fiske, J. (1986), 'Television: Polysemy and popularity', Critical Studies in Communication, 3:4, pp. 391-408.

Gatfield, L. and Millwood Hargrave, A. (2003), Dramatic Licence. Fact or Fiction?, London: Broadcasting Standards Commission.

Geraghty, C. (1991), Women and Soap Opera: A Study of Prime Time Soaps, Cambridge: Polity Press.

Gillespie, M. (1995), Television, Ethnicity and Popular Culture, London: Routledge.

Gonçalves, V. and Patrício, M. (2010), 'Information technology for grandparents and grandchildren', in Proceedings of ICERI2010 Conference, Madrid, Spain, 15-17 November. 
Grandío, M. (2007), 'Recepción de la ficción televisiva norteamericana en España. El caso de Friends'/'Reception of Nord-American TV fiction in Spain. The case of Friends', E-compós. Revista da Associaçao Nacional dos Programas de PósGraduaçao em Comunicaçao, 10, http://compos.org.br/seer/index.php/ecompos/article/viewFile/186/187. Accessed 13 December 2015.

Hall, S. (1997), Representation. Cultural Representation and Signifying Practices, London: Sage.

Han, E. and Lee, S. W. (2014), 'Motivations for the complementary use of text-based media during linear TV viewing: An exploratory study', Computers in Human Behavior, 32, pp. 235-43.

Hobson, D. (1982), Crossroads. The Drama of a Soap Opera, London: Methuen Publishing.

Holliman, R. (2005), 'Reception analyses of science news: Evaluating focus groups as a method', Sociologia e Ricerca Sociale, 26:76-77, pp. 254-64.

Hollows, J. (2000), Feminism, Femininity and Popular Culture, Manchester: Manchester University Press.

Instituto Nacional de Estadística (INE) (2014), 'Informe anual 2014'/‘Annual Report 2014', http://www.ine.es/ine/planine/informe_anual_2014.pdf. Accessed 1 December 2015. 
Isabel (2012-2014, Spain: La1).

Jackson, S. and Vares, T. (2011), 'Media "Sluts": Tween girls' negotiation of postfeminist sexual subjectivities in popular culture', in R. Gill and C. Scharff (eds), New Femininities: Postfeminism, Neoliberalism and Subjectivity, Basingstoke: Palgrave Macmillan, pp. 134-46.

Jenkins, H. (2006), Convergence Culture. Where Old and New Media Collide, New York and London: New York University Press.

Kackman, M., Binfield, M. and Payne, M. T. (2011), Flow TV: Television in the Age of Media Convergence, Nueva York: Routledge.

Kehily, M. J. and Nayak, A. (2008), 'Global femininities: Consumption, culture and the significance of place', Discourse: Studies in the Cultural Politics of Education, $29: 3$, pp. $325-42$.

Lacalle, C. (2010), 'Joves i ficció televisiva: representació i efectes'/‘Young and TV fiction: Representation and effects', Anàlisi, 40, pp. 29-45.

(2012), 'Genre and age in the reception of television fiction', Revista Comunicar, 39: 2, pp. 111-18, http://www.revistacomunicar.com/index.php?contenido=detalles\&numero=39\&articu lo=39-2012-13. Accessed 2 November 2015. 
Landabidea, X. (2014), 'Television as an intergenerational leisure artefact: An interdisciplinary dialogue', Participations, 11:2, pp. 132-55.

Landabidea, X. and Loos, E. (2015), 'Contemporary meanings and experiences of television in the digital age', International Journal of Digital Television, 6:1, pp. 4360.

La que se avecina (2007-, Spain: Tele5).

Lenhart, A., Madden, M., Smith, A. and MacGill, A. (2007), 'Teens and social media', Pew Internet \& American Life Project: Teen Content Creators, http://www.pewinternet.org/2007/12/19/teens-and-social-media/. Accessed 20 November 2015.

Livingstone, S., Allen, J. and Reiner, R. (2001), 'The audience for crime media 194691: A historical approach to reception studies', Communication Review, 4:2, pp. 16592.

Livingstone, S. (2004), 'The challenge of changing audiences: Or what is the researcher to do in the age of Internet?', European Journal of Communication, 19:1, pp. $75-86$. 
(2008), 'Taking risky opportunities in youthful content creation: Teenagers' use of social networking sites for intimacy, privacy, and self-expression', New Media and Society, 10:3, pp. 393-411.

(2009), Children and the Internet: Great Expectations, Challenging Realities, Oxford: Polity Press.

Madill, A. and Goldmeier, R. (2003), 'East enders. Texts of female desire and of community', International Journal of Cultural Studies, 6:4, pp. 471-94.

Modlesky, T. (1982), Loving with a Vengeance. Mass Produced Fantasies for Women, New York: Routledge.

Morales, S. (2015), 'La construcción de la identidad narrativa a través de las "historias de vida mediáticas". Un análisis generacional'/"The construction of narrative identity through "media life stories": A generational analysis', Cultura, Lenguaje y Representación, XIV, pp. 201-20, http://dx.doi.org/10.6035/clr.2015.14.8. Accessed 29 November 2015.

Moreno Minguez, A. (ed.) (2012), La transición de los jóvenes a la vida adulta. Crisis económica y emancipación tardia/The transition from youth to adulthood. Economic crisis and late emancipation'. Colección Estudios Sociales, vol. 34, Barcelona: Obra Social La Caixa.

Morley, D. (1980), The Nationwide Audience, London: British Film Institute. 
Napoli, A. (2014), 'Social media use and generational identity: Issues and consequences on peer-to-peer and cross-generational relationships - an empirical study', Participations. Journal of Audience \& Reception Studies, 11:2, pp. 182-206.

Nicolás, M. T., Padilla, M. A., Quintanilla, C. and Varegas, P. P. (2015), ‘A woman of the 60's caught in a contemporary TV series: Claire Dunphy a housewife in a "Modern Family"”, Communication \& Social Change, 3:1, pp. 19-47, http://dx.doi.org/10.17583/csc.2015.1174. Accessed 30 November 2015.

Noelle-Neumann, E. (1974), 'The spiral of silence. A theory of public opinion', Journal of Communication, 24:2, pp. 43-51.

Peter, J. and Valkenburg, P. M. (2006), 'Adolescents' Internet use: Testing the "disappearing digital divide" versus the "emerging digital differentiation", Poetics, 34: 4-5, pp. 293-305.

Siapera, E. (2004), 'From couch potatoes to cybernauts? The expanding notion of the audience on TV channels' websites', New Media \& Society, 6:2, pp. 155-72.

Siibak, A. and Tamme, V. (2013), 'Who introduced granny to Facebook? An exploration of everyday family interaction in web-based communication environments', Northern Lights, 11:1, pp. 71-89. 
Siibak, A., Vittadini, N. and Nimrod, G. (2014), 'Generations as media audiences: An introduction', Participations. Journal of Audience \& Reception Studies, 11:2, pp. $100-07$.

Scolari, C. A. (2010). 'Media ecology. Map of a theoretical niche', Quaderns del $C A C$, $34(1)$, $17-25$. http://www.cac.cat/pfw files/cma/recerca/quaderns_cac/Q34_Scolari_EN.pdf. Accessed 10 October 2015.

Simons, N. (2013), 'Watching TV fiction in the age of digitization: A study into the viewing practices of engaged TV fiction viewers', International Journal of Digital Television, 4:2, pp. 177-91.

(2014), 'Audience reception of cross- and transmedia TV drama in the age of convergence', International Journal of Communication, 8, pp. 2220-39. http://ijoc.org/index.php/ijoc/article/view/2598/1207. Accessed 20 October 2015.

Tehone, A. B., Zo, H. and Ciganek, A. P. (2015), 'Why do people use social computing? An experiential perspective', Internet Research, 25:3, pp. 338-57, http://dx.doi.org/10.1108/IntR-11-2013-0235. Accessed 10 December 2015.

Turkle, S. (1995), Life on the Screen: Identity in the Age of the Internet, New York: Simon \& Schuster. 
(2015), Reclaiming Conversation. The Power of Talk in a Digital Age, New York: Penguin Books.

Van Cauwenberge, A., Schaap, G. and van Roy, R. (2014), ‘TV no longer commands our full attention: Effects of second-screen viewing and task relevance on cognitive load and learning from news', Computers in Human Behavior, 38, pp. 100-09, http://dx.doi.org/10.1016/j.chb.2014.05.021. Accessed 23 November 2015.

Van den Bulck, J. (2013), 'Cultivation theory: Television fiction as a vector of socialization', in A. N. Valdivia (ed.), The International Encyclopedia of Media Studies, vol. V, Malden, MA: Wiley-Blackwell, pp. 63-88.

Walkerdine, V. (1986), 'Video replay: Families, films and fantasy', in V. Burgin, J. Donald and C. Kaplan (eds), Formations of Fantasy, New York: Routledge, pp. 16799.

Williams, R. (2015), Post-Object Fandom. Television, Identity and Self-narrative, New York: Bloomsbury Academic.

\section{SUGGESTED CITATION}

Lacalle, C. and Pujol, C. (2016), 'Gender, generation and reception of Spanish television fiction in the digital age', International Journal of Digital Television, 7: 2, pp. 217-231, doi: 10.1386/jdtv.7.2.217_1 


\section{CONTRIBUTOR DETAILS}

Charo Lacalle is Full Professor at the Journalism Department at the Autonomous University of Barcelona. She has directed several research projects on TV fiction and Internet, granted by Spanish and International institutions and agencies.

E-mail: Rosario.lacalle@uab.es

Cristina Pujol is Lecturer at the Journalism Department at the Autonomous University of Barcelona. She has several articles on the topics of feminism, cultural identities and media representation and reception.

E-mail: Cristina.Pujol@uab.cat

Notes

${ }^{1}$ http://www.pewinternet.org/2015/10/08/social-networking-usage-2005-2015/. Accessed 20 November 2015.

${ }^{2}$ A total of 47 per cent of television viewing in Spain is done individually (http://www.barloventocomunicacion.es/images/publicaciones/analisis-televisivo2015-a\%20da28dic-Barlovento.pdf, accessed 3 January 2016).

${ }^{3} \mathrm{http}: / / \mathrm{www}$. barloventocomunicacion.es/images/publicaciones/analisis-televisivo2015-a\%20da28dic-Barlovento.pdf. Accessed 3 January 2016.

${ }^{4}$ Report number 9 of the Emancipation Observatory (Youth Council of Spain) reveals that the average age of emancipation of young Spaniards is 28.9, while the European average is 26.1 
(http://politica.elpais.com/politica/2015/12/29/actualidad/1451382467_288187.html, accessed 30 December 2015).

${ }^{5}$ This theory, formulated by the German political scientist Elisabeth Noelle-Neumann (1974), claims that individuals tend to adapt their behaviour to the attitudes they perceive in their environment.

${ }^{6}$ Deferred television consumption represented in Spain, in 2015, 1 per cent of total viewing, equivalent to three minutes per viewer per day (http://www.barloventocomunicacion.es/images/publicaciones/analisis-televisivo2015-a\%20da28dic-Barlovento.pdf, accessed 3 January 2016). 